\title{
Application of Taguchi Experimental Design for identification of factors influence over 3D Printing Time with Fused Deposition Modeling
}

\section{Aplicación del Diseño de Experimentos Taguchi para la identificación de factores de influencias en tiempos de Impresión 3D con Modelado por Deposición Fundida}

\author{
dx.doi.org/10.17981/ijmsor.01.01.06
}

Research Article - Reception Date: November 30, 2015 - Acceptance Date: January 15, 2016

\section{Andrés Sánchez Comas}

Universidad de la Costa

asanchez@cuc.edu.co, Barranquilla, Colombia

\author{
Alexander Troncoso Palacio \\ Universidad de la Costa \\ atroncos1@cuc.edu.co, Barranquilla, Colombia \\ Sonni Troncoso Mendoza \\ Universidad de la Costa \\ stroncos1@cuc.edu.co, Barranquilla, Colombia \\ Dionisio Neira Rodado \\ Universidad de la Costa \\ dneira1@cuc.edu.co, Barranquilla, Colombia
}

To reference this paper:

A. Sánchez Comas, A. Troncoso Palacio, S. Troncoso Mendoza and D. Neira Rodado "Application of Taguchi Experimental Design for identification of factors influence over 3D Printing Time with Fused Deposition Modeling", IJMSOR, vol. 1, no. 1, pp. 43-48, 2016. DOI: dx.doi.org/10.17981/ijmsor.01.01.06

\begin{abstract}
D printing using Fused Deposition Modeling (FDM) is a technology for the manufacture of individual parts with particular or specific applications that cannot be found regularly in the mass market. Printing time can take hours or days, which is a weakness in the technology of $3 \mathrm{D}$ printing. Printing time was analyzed from two perspectives: volume and shape for regular small size pieces. Through 3D print preparation software, simulated printing time can be configured by many parameters that influence both printing time and the print quality. Through this study, under the Taguchi Design of Experiment methodology, could be identified that packing density and print speed are the most influential parameters in printing time, for these kind or pieces.
\end{abstract}

Keywords-- Design of Experiment, Taguchi, 3D Printing, Printing Time, Fused Deposition Modeling, FDM

\begin{abstract}
Resumen-- Impresión 3D utilizando Modelado por Deposición Fundida (MDF) es una de las tecnologías para la fabricación de piezas unitarias con aplicaciones particulares o específicas que regularmente no se encuentran en el mercado a gran escala. El tiempo de impresión puede demorar horas o días, lo cual es una debilidad en la tecnología de Impresión 3D. El tiempo de impresión fue analizado desde dos enfoques: volumen y forma para piezas de tamaño regularmente pequeños. A través de un software de preparación de impresión 3D se simuló un tiempo de impresión estimado, configurando parámetros que pueden influir tanto en los tiempos de impresión como en la calidad de la impresión. A través del presente estudio, bajo la metodología Diseño de Experimento Taguchi, se identificó que la Densidad de Relleno y la Velocidad de Impresión del Relleno son los parámetros más influyentes en el tiempo de impresión para este tipo de piezas.
\end{abstract}

Palabras claves-- Diseño de Experimentos, Taguchi, Impresión 3D, Tiempo de Impresión, Modelado por Deposición Fundida, MDF.

Address correspondence to Andrés Sánchez Comas, Universidad de la Costa,Faculty of Engineering, Department of Industrial Engineering, Calle 58 N 55-66, Barranquilla, Colombia. E-mail: asanchez@cuc.edu.co 


\section{INTRODUCTION}

3D printing using Fused Deposition Modeling technology (FDM), is one of the emerging technologies at global level. Many industrial applications have been developed thanks to this technology like others existing in the market, beyond printing plastic materials (ABS, PLA) for fast prototype of pieces, there are advances in ceramic printing [1], prosthesis and dental implants [2], preparation and training of complex surgeries [3], bone replacement implants [4], food [5], metal [6], and in the case of more radical developments, printing tissue and biological organs [7]. Other applications can be also found in the web like the extrusion of cements for 3D printing houses, jewels and fashion. As can be appreciated, there are innumerable applications of this technology, and there can be much more to be discovered.

$3 \mathrm{D}$ printing through FDM starts with the heating of the extruder from $180^{\circ} \mathrm{C}$ to $230^{\circ} \mathrm{C}$, depending on the type of material to be printed. Once this system is heated, a filament of material with varying diameters between $0.75 \mathrm{~mm}$ and $1.5 \mathrm{~mm}$, is extruded through a nozzle that draws a trajectory on $\mathrm{X}$ and $\mathrm{Y}$ axis. The molten filament is placed on a flat platform with temperatures ranging from $30^{\circ} \mathrm{C}$ to $90^{\circ} \mathrm{C}$ (also called "Heated Bed") drawing a trajectory on $\mathrm{Z}$ axis. $3 \mathrm{D}$ printing preparation software divides the models in layers over $\mathrm{Z}$ axis, whose thickness is determined by the height at which is placed the melted filament from the extruder, depending on the quality to be obtained which can regularly range from $0,1 \mathrm{~mm}$ to $0,25 \mathrm{~mm}$ (layer height). Once the first layer is finished, the extruder is elevated at a distance equivalent to the layer height, and continues to the following application, until finishing printing the object.

Three sections compose the current article, the first one presents an exploration of 3D Printing Technology FDM. The second section describes the study parameters (setting variables of $3 \mathrm{D}$ printing) in FDM Technology that were taken as a study basis and the used orthogonal arrays, as well as other considerations for the experiment. The third section describes the obtained results, and finally, the conclusions of the study are given.

\section{A. Exploration of FDM technology in literature}

3D printing by fused filament was introduced by [8]. However, there are two terms commonly used in literature to refer to $3 \mathrm{D}$ printing technology on which this study is based. One of them is FDF or Fused Deposition Filament. In both, English and Spanish literature there are few authors that refer to this technology with those words, [9] for example, uses it in characterization of rapid prototyping processes, [10] makes a reference in a case of ap- plication of the technology to manufacture a keel replacement for an electric boat propeller, [11] for a case of application of nanocellulose with this technology. The reference [12] refers in this term to the use of the technology in a research about aesthetics in 3D printing, where he found an ample use for textures of surfaces of manufactured pieces. Finally, [13], [14] refers to it as one of the alternatives that a research department would have for an exercise of fast prototypes, however, this author at the same time uses the term "Fused Deposition Modeling" in order to widen the concept of the technology he is referring to.

On the contrary, the use of the term "Fused Deposition Modeling" is found with greater relevance in quantity as well as in the number of quotes, for example, we see that [15], [16] refers with this term to a study of Surface finishing vs deposition time of melted material, [17] refers to it for a study of mechanical featuring of manufactured parts using this technology, [18], [19] in research for the use of polymethylmethacrylate through $3 \mathrm{D}$ printing for the manufacture of implants using FDM technology, and [20] develops a support system of multiobjective decisions to assist users of FDM processes to select the setting variables to achieve specific targets in regard to the characteristics of the parts of the piece to be printed. Finally, referencing the technology like "Fused deposition modeling" for the design and construction of a 3D printer [21], [22].

\section{Methodology}

The employed methodology was based on Taguchi experimental design. This methodology outlines the importance of quality control in an appropriate design of the product and processes to manufacture robust products, and less sensitive to noise factors, the orthogonal arrays of this technology also allow, besides a significant reduction of resources, to determine which factor generates more noise, simplifying many statistical efforts that other methodologies use.

$3 \mathrm{D}$ printing parameters may vary depending on the used management printing software, this study is based on parameter modification using CURA Software. This software is characterized by its practical and friendly graphic interphase, and has 3 setting profiles: Basic, Advanced and Expert, respectively. The variables are mainly configurable as the profiles are changed. The present study grouped the parameters that are influential in the speed of the piece, but do not have a direct impact on the quality of the piece of each of the aforementioned profiles.

Eight parameters were selected as factors for the experiment, and serv as entry parameters for calculating the orthogonal arrays. Parameter description can be seen on Table 1 . 
Table 1. Printing setting Parameters SELECTED AS FACTORS FOR THE EXPERIMENT.

\begin{tabular}{|c|c|c|}
\hline PARAMETER & DESCRIPTION & RECOMMENDATION \\
\hline Layer height & $\begin{array}{l}\text { At less layer } \\
\text { height, greater } \\
\text { the quality }\end{array}$ & $\begin{array}{l}\text { Between } 0.1 \mathrm{~mm} \text { and of } \\
\text { noozle diameter. Layer } \\
\text { height should not be } \\
\text { greather than } 80 \% \text { of } \\
\text { nozzle diameter }\end{array}$ \\
\hline Fill density & Fill Density & $\begin{array}{l}\text { For artistic creations, } \\
\text { shapes or decorative } \\
\text { elements, } 20 \% \text {. For } \\
\text { pieces that must bear } \\
\text { weight or effort, } 80 \% \text {. }\end{array}$ \\
\hline Print speed & $\begin{array}{l}\text { Speed during } \\
\text { the extrusion } \\
\text { of printing } \\
\text { material }\end{array}$ & $\begin{array}{l}\text { At greater speed there } \\
\text { is less printing quality. } \\
28 \mathrm{~mm} / \mathrm{s}\end{array}$ \\
\hline Travel speed & $\begin{array}{l}\text { Speed of } \\
\text { extruder when } \\
\text { travelling from } \\
\text { one point of } \\
\text { the machine to } \\
\text { another }\end{array}$ & $\begin{array}{l}\text { By defect at } 150 \mathrm{~mm} / \mathrm{s} \text {, } \\
\text { although in some } \\
\text { printers can move too } \\
\text { fast, it is recommended } \\
\text { to slow it down at } \\
130 \mathrm{~mm} / \mathrm{s}\end{array}$ \\
\hline $\begin{array}{l}\text { Bottom layer } \\
\text { speed }\end{array}$ & $\begin{array}{l}\text { Important } \\
\text { to adhere } \\
\text { the piece, to } \\
\text { program bottom } \\
\text { layer at low } \\
\text { speed. }\end{array}$ & $\begin{array}{l}\text { One value to obtain } \\
\text { good results in most } \\
\text { printers is } 22 \mathrm{~mm} / \mathrm{s}\end{array}$ \\
\hline Infill speed & $\begin{array}{l}\text { To infill } \\
\text { the piece, } \\
\text { speed can be } \\
\text { considerably } \\
\text { increased } \\
\text { without } \\
\text { affecting its } \\
\text { quality, thus } \\
\text { reducing } \\
\text { printing time }\end{array}$ & $\begin{array}{l}40 \mathrm{~mm} / \mathrm{s} \text { and } \\
\text { progressively increased } \\
\text { until finding the ideal } \\
\text { speed. }\end{array}$ \\
\hline $\begin{array}{l}\text { Outer shell } \\
\text { speed }\end{array}$ & $\begin{array}{l}\text { Piece finishing } \\
\text { depends on it, it } \\
\text { is convenient to } \\
\text { start with a low } \\
\text { speed }\end{array}$ & $\begin{array}{l}25 \mathrm{~mm} / \mathrm{s} \text { is an adequate } \\
\text { speed }\end{array}$ \\
\hline $\begin{array}{l}\text { Inner shell } \\
\text { speed }\end{array}$ & $\begin{array}{l}\text { This parameter } \\
\text { is going to } \\
\text { fix inner } \\
\text { shell speed } \\
\text { (depending on } \\
\text { Shell Thickness } \\
\text { configuration, } \\
\text { we will have a } \\
\text { greater or lesser } \\
\text { number of } \\
\text { these shells) }\end{array}$ & $\begin{array}{l}\text { When shells are not } \\
\text { visible, we can increase } \\
\text { the speed in regard } \\
\text { to the visible shells } \\
\text { without this affecting } \\
\text { the finish of the piece, } \\
\text { initially set this value } \\
\text { in } 30 \mathrm{~mm} / \mathrm{s}\end{array}$ \\
\hline
\end{tabular}

As could be noted, the present study collected a series of recommendations in regard to printing parameters, in order to vary in extremes the values, and structure the levels of the experiment. Three levels for each factor were chosen as can be seen on Table 2.
Table 2. Factors and Levels.

\begin{tabular}{|c|c|c|c|c|c|}
\hline \multicolumn{2}{|c|}{ FACTORS } & UNITS & $\begin{array}{c}\text { LESSER } \\
\text { LEVEL }\end{array}$ & $\begin{array}{c}\text { NOMINAL } \\
\text { LEVEL }\end{array}$ & $\begin{array}{c}\text { HIGHER } \\
\text { LEVEL }\end{array}$ \\
\hline A & $\begin{array}{c}\text { Layer } \\
\text { height }\end{array}$ & $\mathrm{mm}$ & 0,23 & 0,115 & 0,1 \\
\hline C & $\begin{array}{c}\text { Fill } \\
\text { Density }\end{array}$ & $\%$ & 10 & 30 & 50 \\
\hline D & $\begin{array}{c}\text { Print } \\
\text { speed }\end{array}$ & $\mathrm{mm} / \mathrm{s}$ & 10 & 30 & 50 \\
\hline E & $\begin{array}{c}\text { Travel } \\
\text { speed }\end{array}$ & $\mathrm{mm} / \mathrm{s}$ & 100 & 150 & 200 \\
\hline F & $\begin{array}{c}\text { Bottom } \\
\text { layer } \\
\text { speed }\end{array}$ & $\mathrm{mm} / \mathrm{s}$ & 10 & 30 & 50 \\
\hline G & $\begin{array}{c}\text { Infill } \\
\text { speed }\end{array}$ & $\mathrm{mm} / \mathrm{s}$ & 20 & 40 & 60 \\
\hline H & $\begin{array}{c}\text { Outer } \\
\text { shell } \\
\text { speed }\end{array}$ & $\mathrm{mm} / \mathrm{s}$ & 10 & 30 & 50 \\
\hline I & $\begin{array}{c}\text { Inner } \\
\text { shell } \\
\text { speed }\end{array}$ & $\mathrm{mm} / \mathrm{s}$ & 10 & 30 & 50 \\
\hline
\end{tabular}

Based on eight influence factors and three levels, were obtained as options of orthogonal arrays, Taguchi L9 and L27, and orthogonal array L27 was selected, in order to give greater reliability to the study.

After choosing the $3 \mathrm{D}$ printing for FDM to be used, and the experiment determined by Taguchi L27 orthogonal array for a total of 81 arrays, other influential factors were also included, over which printing times can vary: Type or shape of model to be printed, that can generally be of two types of models: Geometrical or Organic, and were set within the Taguchi Experimental Design as signals, in order to identify the behavior of these parameters in front of these types of pieces.

For the present experiment were determined three signals represented in the types of pieces or models to print, no greater than $10 \mathrm{~cm}$ (Height) as can be noted on Fig. 1. The selected models were the following:

a. Geometric Compound: Model that has a cube, a Cone, a Sphere, and a Pyramid.

b. Organic with filling ${ }^{1}$ : Statue of Owl whose shape represents a model of nature.

c. Organic Contour ${ }^{2}$ : Non-geometric Model without filling.

\footnotetext{
${ }^{1}$ Downloaded Model from www.thingiverse.com

${ }^{2}$ Downloaded Model from www.thingiverse.com
} 


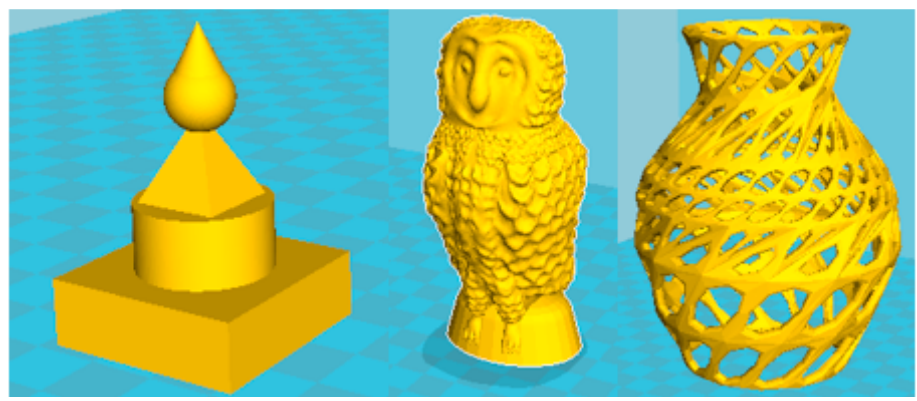

Fig. 1. Geometric Model (left), Organic Model (Center), Organic Contour Model (Right). Source: Author (left), www.thingiverse.com (Center and Right)

Two experiments were projected, the first one consisted in the exploration of the most influential factors, in it were analyzed eight factors and the three signals formerly set out, the objective was to discard the less influential factors through the results of the analysis graphs of signal-noise relation that would yield the Minitab statistics software.

With the most influential factors identified, it would be carried out a second experiment in order to validate the most influential parameters of the results of first experiment through a new Taguchi Orthogonal Array that would be determined by the amount of selected factors, to be also analyzed through the signal-noise relation graph.

The resulting values were obtained from printing time simulation yielded by CURA 3D printing software through the variation of printing parameters (Factors of Experiment Design) and registered in Minitab the simulation values, replica of the experiment that was carried out for each se- lected 3D model that act as signal-noise within the design of Taguchi experiment.

\section{RESULTS}

The exploration experiment yielded as a result that the factors (B) Fill Density, (F) Infill Speed, (G) Outer Shell Speed and (H) Inner Shell Speed, are the most influential factor from greater to lesser mayor impact in printing times, this can be confirmed in Fig. 2.

With these four factors of greater influence, a second Taguchi Experimental Design was carried out to validate the influential factors, which for four factors, three Levels and the same three signals (types of printing pieces), determined an L9 orthogonal array to do 27 more combinations.

The executed statistical analysis in Minitab, ratified that the most influential printing parameters in printing times are Fill Density, and Infill Speed as can be seen on Fig. 3.
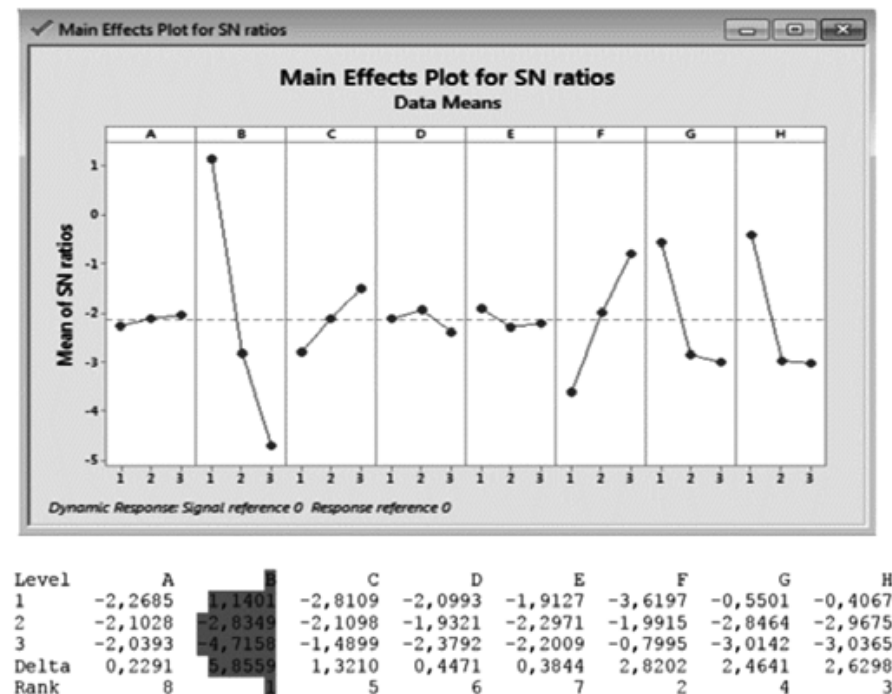

Fig. 2. Signal-Noise Relation Graphic of the Exploration Experiment obtained from Minitab 


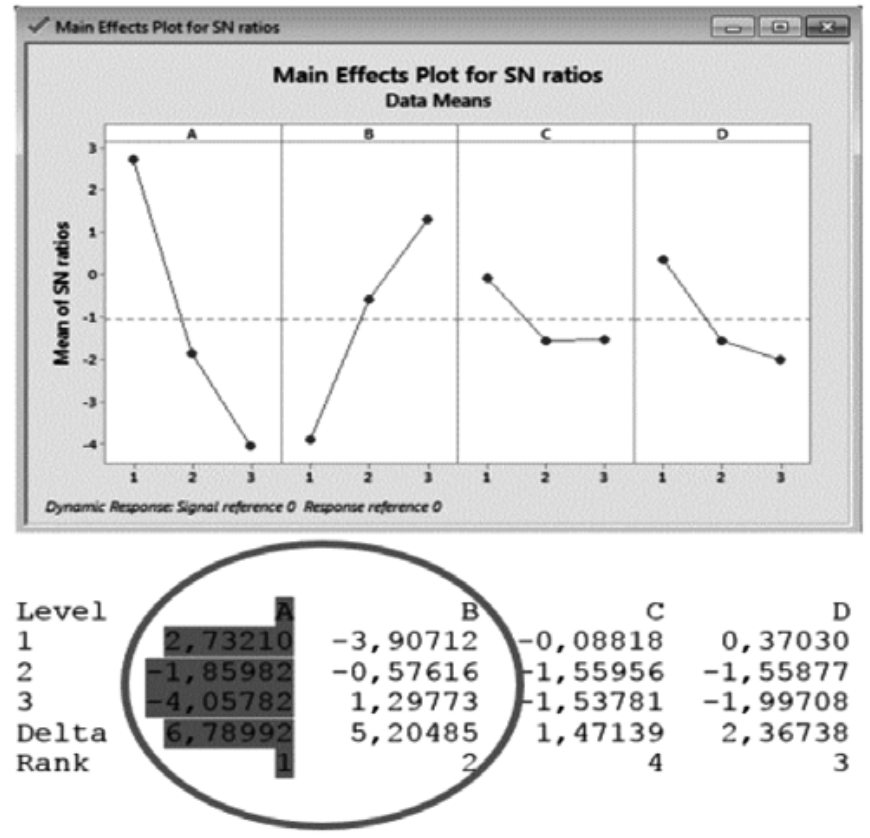

Fig. 3. Signal-Noise Relation Graphic of the Validation Experiment obtained from Minitab

\section{Conclusions}

Using Taguchi Orthogonal Arrays to Design Experiments, varying in three levels, eight printing parameters taken as factors, it was determined that the most influential factors on printing times for relatively small pieces are Fill Density, and Infill Speed, and that Layer Height, Printing Speed, Travel Speed and Bottom Layer Speed have no great influence on printing times. It is recommended for next researches to determine the relation between printing times and the quality of hollow pieces with thick contours that help ensure the integrity of printing, using clear, printing supports for it, internal as well as external. Besides, an ample DOE must be performed to include pieces of small height and width, medium and big, considering the printing areas of the 3D FDM printers, as well as the comparisons of several 3D printing preparation software.

\section{REFERENCES}

[1] R. Clancy and V. Jamalabad, "Fused deposition of ceram ics: progress towards a robust and controlled process for commercialization," Solid Free. Fabr. Proc., no. December 2015, pp. 185-194, 1997.

[2] R. E. Jung, D. Schneider, J. Ganeles, D. Wismeijer, M. Zwahlen, C. H. F. Hämmerle, and A. Tahmaseb, "Computer technology applications in surgical implant dentistry: a systematic review.," Int. J. Oral Maxillofac. Implants, vol. 24 Suppl, pp. 92-109, 2009.

[3] G. T. Klein, Y. Lu, and M. Y. Wang, "3D printing and neurosurgery--ready for prime time?," World Neurosurg., vol. 80, no. 3-4, pp. 233-5, Jan. 2013.
[4] C. Bergmann, M. Lindner, W. Zhang, K. Koczur, A. Kirsten, R. Telle, and H. Fischer, "3D printing of bone substitute implants using calcium phosphate and bioactive glasses," J. Eur. Ceram. Soc., vol. 30, no. 12, pp. 2563-2567, Sep. 2010.

[5] D. Southerland, P. Walters, and D. Huson, "Edible 3D Printing," in Digital Fabrication 2011 Conference, NIP 27, 27th International Conference on Digital Printing Technologies, 2011, pp. 819-822.

[6] E. Bassoli, A. Gatto, L. Iuliano, and M. G. Violante, "3D printing technique applied to rapid casting," Rapid Prototyp. J., vol. 13, no. 3, pp. 148-155, Jun. 2007.

[7] C. Schubert, M. C. van Langeveld, and L. A. Donoso, "Innovations in 3D printing: a 3D overview from optics to organs.," Br. J. Ophthalmol., vol. 98, no. 2, pp. 159-61, Feb. 2014.

[8] M. M. N. S. Scott Crump, "Apparatus and method for creating three-dimensional objects," 1992.

[9] F. Munguia, "Caracterización de los procesos de Prototipado Rápido como herramienta de diseño para la fabricación rápida," in X Congreso Internacional de Ingenieria de Proyectos, 2006, pp. 13-15.

[10] R. Rodriguez, A. Hernandez, and C. Rainer, "Impresión 3D de repuesto de quilla para propulsor eléctrico de embarcaciones.” Instituto de Ciencias y Tecnologías e Innovación, 2015.

[11] C. Rainer and R. Muzos, "Nanocelulosa - Primeros Pininos en El Salvador." Instituto de Ciencias y Tecnologias de la Innovacion, Valencia, 2015.

[12] P. O'Dowd, S. Hoskins, P. Walters, and A. Geisow, "Modulated Extrusion for Textured 3D Printing," in NIP \& Digital Fabrication Conference, 2015, pp. 173178.

[13] A. Gómez Cabrera and A. R. Orozco Ovalle, "Simulación digital como herramienta para la gestión del conocimiento en la construcción de edificaciones en concreto," INGE CUC, vol. 10, no. 1, pp. 75-82, 2014.

[14] P. Dubois, A. Aoussat, and M. Le Coq, "A method to formalize the rapid prototyping process," Int. J. Comput. Appl. Technol., vol. 12, no. 2-5, Jan. 1999. 
[15] K. Thrimurthulu, P. M. Pandey, and N. Venkata Reddy, "Optimum part deposition orientation in fused deposition modeling," Int. J. Mach. Tools Manuf., vol. 44, no. 6 , pp. 585-594, May 2004.

[16] A. P. Cortés Vásquez, "Sistema de Aprendizaje de Patrones de Navegación Web Mediante Gramáticas Probabilísticas de Hipertexto," INGE CUC, vol. 11, no. 1, pp. 72-78, 2015. Doi: 10.17981/ingecuc.11.1.2015.07

[17] A. Bellini and S. Güçeri, "Mechanical characterization of parts fabricated using fused deposition modeling," Rapid Prototyp. J., vol. 9, no. 4, pp. 252-264, Oct. 2003.

[18] D. Espalin, K. Arcaute, D. Rodriguez, F. Medina, M. Posner, and R. Wicker, "Fused deposition modeling of patient-specific polymethylmethacrylate implants," Rapid Prototyp. J., vol. 16, no. 3, pp. 164-173, Apr. 2010.
[19] A. Cama Pinto, E. De la Hoz Franco, and D. Cama Pinto, "Las redes de sensores inalámbricos y el internet de las cosas," INGE CUC, vol. 8, no. 1, pp. 163-172, 2012.

[20] C. W. Ziemian and P. M. Crawn, "Computer aided decision support for fused deposition modeling," Rapid Prototyp. J., vol. 7, no. 3, pp. 138-147, Aug. 2001.

[21] C. E. Gómez Montoya, C. A. Candela Uribe, and L. E. Sepúlveda Rodríguez, "Seguridad en la configuración del servidor web Apache," INGE CUC, vol. 9, no. 2, pp. 31-38, 2013.

[22] E. Torres, J. León, and E. Torres, "Diseño y construcción de una impresora 3D aplicando la técnica de prototipado rápido modelado por deposición fundida," in 3er Congreso Internacional de Ingeniería Mecatronica, 2012, pp. $1-15$. 